\title{
Quality of extra virgin olive oil affected by several packaging variables
}

\author{
By José Luis Guil-Guerrero* and Joaquín Urda-Romacho
}

\author{
Área de Tecnología de Alimentos, Universidad de Almería, \\ 04120 Almería, Spain \\ ( ${ }^{*}$ Corresponding author e-mail: jlguil @ual.es)
}

\section{RESUMEN}

Efectos de algunas variables del envasado en la calidad de aceite de oliva virgen extra.

El objetivo de este estudio fue determinar la evolución de los índices de calidad de tres variedades de aceite de oliva virgen extra (EVOO), almacenado según diferentes condiciones durante un año. Los parámetros de calidad seleccionados fueron: índice de acidez, valor de peróxidos (PV), coeficiente K270, perfil de ácidos grasos (FAs), carotenoides y clorofila. El estudio fue realizado analizando mensualmente tres variedades de EVOO: -Picual, Hojiblanca y Arbequinaobtenidas de la cosecha anual, envasado en botellas oscuras y transparentes de cristal. Otro aceite Picual envasado en depósitos fue también analizado mensualmente. Los resultados muestran que la acidez y el índice $\mathrm{K}_{270}$ aumentaron ligeramente en todos los casos, mientras que las variaciones del PV fueron más significativas en EVOO almacenado en botellas transparentes de cristal. Los cambios de perfiles de FAs fueron mínimos durante todo el período de almacenamiento, aunque el ácido oleico aumentó ligeramente al final del período de almacenamiento, especialmente en el aceite Picual almacenado en depósitos. En cuanto a los pigmentos evaluados, las pérdidas de clorofilas fueron más notables que las de carotenoides. En conclusión, el mejor sistema de envase para el EVOO fue el depósito, seguido de las botellas de cristal obscuras. Por otra parte, se ha demostrado que un EVOO procedente de la cosecha previa y almacenado bajo atmósfera de nitrógeno, puede ser envasado en botellas de cristal sin cambios de calidad apreciables, comparado con EVOO envasado en las mismas botellas y obtenido en la cosecha anual.

PALABRAS CLAVE: Aceite de oliva virgen extra - Acido oleico - Almacenamiento de aceite de oliva - Variedades de aceite de oliva.

\section{SUMMARY}

Quality of extra virgin olive oil affected by several packaging variables

The aim of this study was to determine the evolution of the quality index of three extra-virgin olive oil varieties (EVOO), stored according to different packaging variables for one year. The selected quality parameters were: acidity index, peroxide value (PV), $\mathrm{K}_{270}$ coefficient, fatty acid (FA) profile, carotenoids and chlorophylls. This study was carried out by monthly analyzing several bottled EVOO varieties Picual, Hojiblanca and Arbequina- obtained during the present harvesting season. In addition, other Picual EVOO stored in a mill deposit, as well as bottled Picual EVOO from the previous harvesting season were analyzed monthly. The oils were packaged in dark and transparent glass bottles. The results showed that the acidity and $\mathrm{K}_{270}$ parameters increased slightly in all cases, while PV value changes were significant in EVOOs stored in transparent glass bottles. FA profiles were slightly modified throughout the storage period, although oleic acid slightly increased at the end of the analytical period, especially in the EVOO stored in deposits. Regarding pigment, chlorophylls losses were more noticeable than those related to carotenoid. According to the present results, the best packaging conditions for EVOO were deposits, followed by dark glass bottles. In addition, this study demonstrated that EVOO collected from the previous harvesting season and stored under nitrogen atmosphere could be packaged in glass bottles without appreciable quality changes, as compared with EVOO packaged in the same bottles and obtained during the current harvesting season.

KEY-WORDS: Extra virgin - Oleic acid - Olive oil - Olive oil storage - Olive oil varieties.

\section{INTRODUCTION}

The Mediterranean diet is an eating pattern characterizing a lifestyle and culture that has been reported to contribute to better health and quality of life for those who adhere to it. Mediterranean food tradition is sustained by three basic essentials: wheat, olives and grapes. Nevertheless, olive oil is the central element inherent to this diet, and its health benefits have been considered only in the last few decades (Psomiadou and Tsimidou, 2002).

According to olive variety, EVOO has different sensorial attributes, e.g. fragrance, flavor, color, and nutrient composition parameters. Thus, the quality of the EVOO can be considered from diverse points of view: normative, commercial, nutritional, therapeutic and sensorial. These last three are closely related to the chemical composition of the oil (Uceda and Hermoso, 1998). Some parameters like acidity, PV and UV absorbance must appear on the label of the product. These parameters, indicators of the quality of the EVOO, can vary depending on time and storage method, reaching undesirable values at the 
end of the shelf-life. In this sense, acidity increases with time, both stored in the dark and exposed to light (Gómez-Alonso et al., 2007). Nowadays, consumers are imposing an increasing demand for a higher quality of EVOO during the shelf-life period. This expectation is a consequence not only of the fundamental requirement that food must continue to be safe but of the necessity to reduce undesired changes in sensorial quality to a minimum (Hrncirik and Fritsche, 2005).

With respect to quality preservation, the literature shows different results in some essayed storage conditions. For example, in samples obtained from Leccino and Coratina cultivars, Giovacchino et al. (2002) report that the PV of oils increased over the limit value allowed by European Union law when the bottles were only partly filled and air was the conditioner gas. In addition, Caponio et al. (2005) and Vekiari et al. (2007) report that the shelf life of the oils exposed to intense artificial light and diffused daylight is shorter than that of oils kept in the dark. Thus, factors affecting olive oil quality during storage are temperature, exposure to light and contact with oxygen. Light is an initiator of reactions that lead to the deterioration of the oil, and sensitizers such as chlorophyll may play a role in promoting photooxidation (Kiritsakis, 1984). In addition, the type of packaging has a dramatic effect on the shelf life of the oils. Oils being carefully processed to maximize palatability may be damaged by the improper selection of the storage container. Thus, it is desirable to maintain the product quality at an optimum level for the longest shelf-life period (Vekiari et al., 2002). In order to better understand loss in quality, experimental and theoretical investigations of packaged olive oil have been conducted to a predictive model based on mathematical predictions to develop a quality indicator (Coutelieris and Kanavouras, 2006). Nevertheless, Pagliarini et al. (2000) in Tuscan (Italy) EVOO, indicate that stability was not significantly influenced by different uncontrolled bottling methods, transport or storage conditions in supermarkets. In any case, it has been suggested that an urgent change in olive oil packaging methods is needed to maintain the quality characteristics of the product (Psomiadou and Tsimidou, 2002).

Concerning EVOO nutrient changes during storage, in the Arbequina variety, Morelló et al. (2004) reported an increase in OA percentages in the FA composition after 12 months of storage. Other minor components of EVOO, such as tocopherols, carotenoids and chlorophylls diminished quickly in samples stored in the dark (Gallardo-Guerrero et al. 2005; Kanavouras and Coutelieris, 2006).

Results from these studies have contributed to a better understanding of the quality variables affecting EVOO; however, they are not conclusive results for all EVOO varieties, nutrient composition and storage variables. Thus, a detailed forecast of EVOO shelf-life is necessary for consumer information since most producers consider 12-18 months as the maximum storage period prior to consumption (Morelló et al., 2004).

Although some conclusions exist concerning the preservation of packaged EVOO, the study of a real situation in a food industry and/or markets, that clarifies for scientists, consumers and distributors how EVOO could be better preserved, still remains untested. In addition, the possible quality of an EVOO obtained from previous crops and bottled simultaneously with other seasonal EVOOs needs to be clarified.

In this work, the loss in quality of seasonal and one-year old EVOOs stored in different types of glass packages and deposits has been studied. The main target was to determine the best packing and storage methods for EVOO. Changes in EVOO quality was evaluated for different varieties: Picual, Arbequina and Hojiblanca, over a 12 month period.

\section{MATERIALS AND METHODS}

\subsection{Extra virgin olive oil}

Recently extracted Picual, Arbequina and Hojiblanca EVOOs were collected from industrial oil mills located in the Tabernas Desert (Almería, Spain) during the crop seasons 2004/05.

\subsection{Storage conditions}

In January of 2005, an appropriate number of $0.5 \mathrm{~L}$ transparent and dark glass bottles were filled with the above indicated EVOO varieties. Other Picual EVOO obtained in the previous crop season that remained stored in an inert deposit (under nitrogen atmosphere), was also used to fill several transparent and dark glass bottles. In addition, a seasonal Picual EVOO stored in a deposit at $20^{\circ} \mathrm{C}$ was analyzed monthly. The bottles were arranged in agreement with market oil storage, although avoiding exposure to direct sunlight, under an annual cycle of temperatures similar to that of any other trade, but under environmental refrigeration during the summer $\left(25^{\circ} \mathrm{C}\right)$. All EVOOs stored in bottles, as well as the Picual EVOO from the deposit were analyzed monthly. It is necessary to emphasize that this analytical scheme was carried out to know the quality of the oils commercialized by the sponsoring company of this study.

\subsection{Analytical determinations}

All reagents used were of analytical or spectroscopic grade, and were supplied by Panreac (Barcelona $a_{1}$ Spain).

\section{Analytical index}

The determination of legal quality characteristics of EVOO: titratable acidity, PV, and extinction coefficients $\left(\mathrm{K}_{270}\right)$, was carried out following the 
analytical methods described in the Regulations EEC/2568/91 of the European Union Commission (1991). Titratable acidity was expressed as the amount of oleic acid as \%. PV was expressed as milliequivalents of active oxygen per kilogram of oil (mEq. $\mathrm{O}_{2} / \mathrm{kg}$ oil), and extinction coefficient $K_{270}$ was expressed as the specific extinctions of a $1 \%(\mathrm{w} / \mathrm{v})$ solution of oil in 2, 2, 4-trimethylpentane in $1 \mathrm{~cm}$ cell path length.

\section{FA composition}

Methyl esters of FA (FAME) were prepared by treatment of the EVOO with acetyl chloride and methanol (Lepage and Roy, 1984). The FAME were analyzed by comparing their retention times with those for standads ("Rapeseed oil mix" and "PUFAS-1", from Sigma ${ }^{\circledR}$ ), using Gas-Liquid Chromatography (GLC) in a Hewlett-Packard HP5890 series II chromatograph provided with a flame ionization detector and HP3394 integrator. A capillary column of high polarity fused silica was used (Supelco SP2330; length: $30 \mathrm{~m}$; internal diameter: $0.25 \mathrm{~mm}$; thickness of the film: $0.2 \mu \mathrm{m}$ ). The flow of carrier gas $\left(\mathrm{N}_{2}\right)$ was $0.75 \mathrm{~L} / \mathrm{min}$, and the split ratio of the injector was 100:1. The injector temperature was $240^{\circ} \mathrm{C}$ and the detector temperature was $260^{\circ} \mathrm{C}$. The starting temperature of the oven was $205^{\circ} \mathrm{C}$ and was increased at a rate of $6^{\circ} \mathrm{C} / \mathrm{min}$ until it reached $240^{\circ} \mathrm{C}(5.83 \mathrm{~min})$. The injection volume was $5 \mu \mathrm{L}$ and a blank was run after every two analyses. Peaks were identified using standard FAMEs and quantified using methyl nonadecanoate (19:0) as an internal standard.

\section{Chlorophyll and Carotenoid determinations}

Chlorophyll and carotenoids were determined at 472 and $670 \mathrm{~nm}$ in cyclohexane, using specific extinction values, according to the method of Mínguez- Mosquera et al. (1990).

\subsection{Statistical Analysis}

Experimental results were expressed as the mean \pm S.D. of five parallel measurements. A Multifactorial Analysis of the Variance (ANOVA) was made with the data obtained from each EVOO variety at different times and stored under different conditions. $P$ values $<0.05$ were regarded as significant.

\section{RESULTS AND DISCUSSION}

The initial composition of each EVOO at the start of the analytical period is shown in Table 1. All samples fulfil the requirements EEC Regulations for EVOO: acidity, $\mathrm{PV}$ and $\mathrm{K}_{270}$. The amount of free FAs is an indicator of the quality and is traditionally used as an indicator for the classification of the different commercial types from EVOO. It can be seen that at the beginning of this study, all EVOO varieties showed an acidity index $\leq 0.1 \%$, which is much lower than the regulated $0.8 \%$ as maximum for any EVOO. Concerning PV, this index is considered to be an indicator of primary oxidation. All varieties considered here showed low PV values, with the Picual variety at the bottom of the range with 2.0 meq $\mathrm{O}_{2} / \mathrm{kg}$ oil, while Arbequina variety yielded the highest value, with 5.6 meq $\mathrm{O}_{2} / \mathrm{kg}$ oil. In any case, none of the analyzed oils surpassed 20 meq $\mathrm{O}_{2} / \mathrm{kg}$ oil, which is the limit that is established for EVOO (EEC Regulations). Another

Table 1

Initial composition and quality index of different EVOO varieties

\begin{tabular}{|c|c|c|c|c|}
\hline & \multicolumn{2}{|c|}{ Picual } & \multirow[b]{2}{*}{ Hojiblanca $^{c}$} & \multirow[b]{2}{*}{ Arbequina $^{c}$} \\
\hline & $\begin{array}{c}\text { Present harvesting } \\
\text { season }^{\mathrm{a}}\end{array}$ & $\begin{array}{c}\text { Previous harvesting } \\
\text { season }^{\mathrm{b}}\end{array}$ & & \\
\hline Free acidity (\%) & $0.12 \pm 0.01$ & $0.12 \pm 0.02$ & $0.12 \pm 0.02$ & $0.14 \pm 0.01$ \\
\hline PV (mEq. O2/ kg oil) & $1.8 \pm 0.05$ & $2.2 \pm 0.16$ & $3.7 \pm 0.12$ & $5.9 \pm 0.11$ \\
\hline $\mathrm{K} 270$ & $0.06 \pm 0.01$ & $0.08 \pm 0.01$ & $0.05 \pm 0.01$ & $0.06 \pm 0.01$ \\
\hline Carotenoids (ppm) & $6.7 \pm 0.02$ & $10.7 \pm 0.03$ & $6.5 \pm 0.02$ & $5.3 \pm 0,01$ \\
\hline Chlorophyls (ppm) & $8.0 \pm 0.11$ & $15.8 \pm 0.09$ & $4.6 \pm 0.17$ & $6.2 \pm 0.11$ \\
\hline C16:0 (\%) & $11.61 \pm 0.05$ & $12.1 \pm 0.08$ & $10.2 \pm 0.03$ & $16.1 \pm 0.03$ \\
\hline C16:1n-9 (\%) & $1.14 \pm 0.04$ & $0.9 \pm 0.02$ & $0.71 \pm 0.03$ & $2.1 \pm 0.02$ \\
\hline C18:0 (\%) & $3.53 \pm 0.02$ & $3.2 \pm 0.03$ & $3.5 \pm 0.03$ & $2 \pm 0.03$ \\
\hline C18:1n-9 (\%) & $77.4 \pm 0.03$ & $79.8 \pm 0.03$ & $74.5 \pm 0.03$ & $64.5 \pm 0.02$ \\
\hline C18:2n-6 (\%) & $5.36 \pm 0.02$ & $3.1 \pm 0.08$ & $9.9 \pm 0.05$ & $14.1 \pm 0.03$ \\
\hline C18:3n-3 (\%) & $0.72 \pm 0.03$ & $0.7 \pm 0.06$ & $1.1 \pm 0.06$ & $0.86 \pm 0.02$ \\
\hline
\end{tabular}


quality index specified in EEC Regulations is $\mathrm{K}_{270}$. An increase indicates that oil oxidation has begun, which could be due to some factors affecting storage conditions or to an inadequate EVOO processing. In this study, all varieties showed $\mathrm{K}_{270}$ coefficients less than 0.1 , compared to a maximum established by EEC Regulations for EVOO $\leq 0.22$.

Other quality parameters analyzed during EVOO storage were FAs, carotenoids and chlorophylls. The relative FA percentages were characteristics of the EVOO varieties here analyzed. Thus, Picual variety showed the highest $O A$ value $(77.4 \%)$, and a scarce amount of linoleic acid (LA, 18:2n-6) (5.5\%). In contrast, Arbequina variety showed the lowest values for OA (64.5\%). Nevertheless, polyunsaturated fatty acids (PUFAs) content in this variety were in the top of the range, due to a high LA content, although this EVOO also showed the highest percentage of palmitic acid (PA, 16:0), $16.1 \%$. Finally, Hojiblanca variety had a $74.5 \% \mathrm{OA}$ and $9.9 \%$ LA, showing the lowest values for saturated FAs, with $10.2 \%$ PA.

The amount of chlorophylls and carotenoids in olives, as occurs in most fruits, strongly depends on the ripening stage and, as noted in this work, EVOO variety $(p<0.05)$. Surprisingly, Picual EVOO from the previous harvesting season and stored under nitrogen atmosphere in deposits, showed the highest values for both parameters.
Acidity index evolution is shown in Table 2. Notice that it barely increased in EVOO packaged in all bottles throughout the storage period, although it does not exceed the initial values of $0.1 \%$ for bottled Picual and Hojiblanca varieties. The Arbequina variety shows the highest increase for this index at the end of the storage period, with $0.17 \%$ as its final value. It can be observed that from the third month of storage the acidity index increases in all varieties, especially in Picual and Hojiblanca EVOOs. These results agree with the observations made by Tawfik and Huyghebaert (1997), who report an increase of acidity for EVOO stored in bottles.

The evolution of PV is shown in Table 3. As occurs with the previous index, it increased with time in all samples $(p<0.05)$, especially in Arbequina EVOO placed in transparent glass bottles, which reached the highest levels at the end of the analytical period. This fact could be due to a high initial amount of LA in Arbequina EVOO, which constitutes an adequate target for any factor that started EVOO oxidation, such as oxygen and possible metal content in the EVOO, light exposure, and so on. On the other hand, the lowest increase in PV was found in EVOO stored in deposits. This could be attributed to the fact that EVOO in deposits has not yet been poured, and therefore lacks intense contact with atmospheric oxygen. These results disagree with the findings of Okogeri and

Table 2

Free acidity evolution in three EVOO varieties stored under different variables for a 12 month period

Olive oil varieties $†, \ddagger$

\begin{tabular}{lccccccccc}
\cline { 2 - 9 } & \multicolumn{4}{c}{ Months } & \multicolumn{4}{c}{ Picual } & \multicolumn{2}{c}{ Hojiblanca } & Arbequina \\
\cline { 2 - 11 } & ${ }^{1}$ Mill & ${ }^{2}$ Dark bot. & $\begin{array}{c}{ }^{2} \text { Transparent } \\
\text { bot. }\end{array}$ & $\begin{array}{c}{ }^{3} \text { Inert dark } \\
\text { bot. }\end{array}$ & $\begin{array}{c}{ }^{3} \text { Inert transpar- } \\
\text { ent bot. }\end{array}$ & $\begin{array}{c}{ }^{2} \text { Dark } \\
\text { bot. }\end{array}$ & $\begin{array}{c}{ }^{2} \text { Trasparent } \\
\text { bot. }\end{array}$ & $\begin{array}{c}{ }^{2} \text { Dark } \\
\text { bot. }\end{array}$ & $\begin{array}{c}{ }^{2} \text { Transparent } \\
\text { bot. }\end{array}$ \\
\hline $\mathrm{Ja}$ & $0.12 \mathrm{a}$ & $0.12 \mathrm{a}$ & $0.12 \mathrm{a}$ & $0.12 \mathrm{a}$ & $0.12 \mathrm{a}$ & $0.12 \mathrm{a}$ & $0.12 \mathrm{a}$ & $0.14 \mathrm{a}$ & $0.14 \mathrm{a}$ \\
\hline $\mathrm{Fe}$ & $0.12 \mathrm{a}$ & $0.12 \mathrm{a}$ & $0.12 \mathrm{a}$ & $0.12 \mathrm{a}$ & $0.12 \mathrm{a}$ & $0.12 \mathrm{a}$ & $0.12 \mathrm{a}$ & $0.14 \mathrm{a}$ & $0.14 \mathrm{a}$ \\
\hline $\mathrm{Mr}$ & $0.12 \mathrm{a}$ & $0.12 \mathrm{a}$ & $0.12 \mathrm{a}$ & $0.12 \mathrm{a}$ & $0.12 \mathrm{a}$ & $0.12 \mathrm{a}$ & $0.12 \mathrm{a}$ & $0.14 \mathrm{a}$ & $0.14 \mathrm{a}$ \\
\hline $\mathrm{Ap}$ & $0.13 \mathrm{a}$ & $0.12 \mathrm{a}$ & $0.13 \mathrm{a}$ & $0.12 \mathrm{a}$ & $0.13 \mathrm{a}$ & $0.13 \mathrm{a}$ & $0.13 \mathrm{a}$ & $0.14 \mathrm{a}$ & $0.14 \mathrm{a}$ \\
\hline $\mathrm{My}$ & $0.13 \mathrm{a}$ & $0.12 \mathrm{a}$ & $0.13 \mathrm{a}$ & $0.12 \mathrm{a}$ & $0.13 \mathrm{a}$ & $0.13 \mathrm{a}$ & $0.13 \mathrm{a}$ & $0.16 \mathrm{a}, \mathrm{b}$ & $0.16 \mathrm{~b}$ \\
\hline $\mathrm{Je}$ & $0.13 \mathrm{a}$ & $0.13 \mathrm{a}$ & $0.13 \mathrm{a}$ & $0.12 \mathrm{a}$ & $0.13 \mathrm{a}$ & $0.13 \mathrm{a}$ & $0.13 \mathrm{a}$ & $0.16 \mathrm{a}, \mathrm{b}$ & $0.16 \mathrm{~b}$ \\
\hline $\mathrm{Jl}$ & $0.13 \mathrm{a}$ & $0.13 \mathrm{a}$ & $0.13 \mathrm{a}$ & $0.12 \mathrm{a}$ & $0.13 \mathrm{a}$ & $0.14 \mathrm{a}, \mathrm{b}$ & $0.14 \mathrm{a}$ & $0.16 \mathrm{a}, \mathrm{b}$ & $0.16 \mathrm{~b}$ \\
\hline $\mathrm{Ag}$ & $0.13 \mathrm{a}$ & $0.13 \mathrm{a}$ & $0.14 \mathrm{a}$ & $0.12 \mathrm{a}$ & $0.14 \mathrm{a}$ & $0.14 \mathrm{a}, \mathrm{b}$ & $0.14 \mathrm{a}$ & $0.16 \mathrm{a}, \mathrm{b}$ & $0.17 \mathrm{~b}, \mathrm{c}$ \\
\hline $\mathrm{Se}$ & $0.13 \mathrm{a}$ & $0.13 \mathrm{a}$ & $0.14 \mathrm{a}$ & $0.13 \mathrm{a}$ & $0.14 \mathrm{a}$ & $0.14 \mathrm{a}, \mathrm{b}$ & $0.14 \mathrm{a}$ & $0.16 \mathrm{a}, \mathrm{b}$ & $0.18 \mathrm{c}$ \\
\hline $\mathrm{Oc}$ & $0.13 \mathrm{a}$ & $0.14 \mathrm{a}$ & $0.14 \mathrm{a}$ & $0.13 \mathrm{a}$ & $0.14 \mathrm{a}$ & $0.14 \mathrm{a}, \mathrm{b}$ & $0.14 \mathrm{a}$ & $0.16 \mathrm{a}, \mathrm{b}$ & $0.18 \mathrm{c}$ \\
\hline $\mathrm{No}$ & $0.13 \mathrm{a}$ & $0.14 \mathrm{a}$ & $0.14 \mathrm{a}$ & $0.13 \mathrm{a}$ & $0.14 \mathrm{a}$ & $0.15 \mathrm{~b}$ & $0.14 \mathrm{a}$ & $0.17 \mathrm{~b}$ & $0.19 \mathrm{c}$ \\
\hline $\mathrm{De}$ & $0.13 \mathrm{a}$ & $0.14 \mathrm{a}$ & $0.14 \mathrm{a}$ & $0.14 \mathrm{a}$ & $0.14 \mathrm{a}$ & $0.15 \mathrm{~b}$ & $0.14 \mathrm{a}$ & $0.17 \mathrm{~b}$ & $0.19 \mathrm{c}$ \\
\hline
\end{tabular}

† Standard deviations were routinely less than $5 \%$ of the means

$\ddagger$ Means within a column followed by the same letter are not significantly different $(p \leq 0.05)$ by the Duncan's Multiple Range Test 1 EVOO from the present harvest season stored in deposits 2 Bottled EVOO from the present harvest season 3 Remaining EVOO from the previous harvest season stored in inert mill and bottled simultaneously with seasonal EVOO 
Table 3

Peroxide value evolution in three EVOO varieties stored under different variables for a 12 month period

\begin{tabular}{|c|c|c|c|c|c|c|c|c|c|}
\hline \multirow{3}{*}{ Months } & \multicolumn{9}{|c|}{ Olive oil varieties $^{\dagger, \neq}$} \\
\hline & \multicolumn{5}{|c|}{ Picual } & \multicolumn{2}{|c|}{ Hojiblanca } & \multicolumn{2}{|c|}{ Arbequina } \\
\hline & ${ }^{1}$ Mill & ${ }^{2}$ Dark bot. & $\begin{array}{c}{ }^{2} \text { Transparent } \\
\text { bot. }\end{array}$ & $\begin{array}{c}{ }^{3} \text { Inert. dark } \\
\text { bot. }\end{array}$ & $\begin{array}{c}{ }^{3} \text { Inert. } \\
\text { transparent bot. }\end{array}$ & ${ }^{2}$ Dark bot. & $\begin{array}{c}{ }^{2} \text { Transparent } \\
\text { bot. }\end{array}$ & ${ }^{2}$ Dark bot. ${ }^{2}$ & $\begin{array}{c}{ }^{2} \text { Transparent } \\
\text { bot. }\end{array}$ \\
\hline $\mathrm{Ja}$ & $2.0^{a}$ & $2.0^{\mathrm{a}}$ & $2.0^{\mathrm{a}}$ & $2.2^{\mathrm{a}}$ & $2.2^{\mathrm{a}}$ & $3.5^{a}$ & $3.5^{\mathrm{a}}$ & $5.6^{a}$ & $5.6^{\mathrm{a}}$ \\
\hline $\mathrm{Fe}$ & $3.2^{b}$ & $2.8^{a}$ & $3.2^{b, c}$ & $2.9^{a}$ & $3.3^{a, b}$ & $4.2^{a, b}$ & $5.3^{b}$ & $6.4^{\mathrm{a}, \mathrm{b}}$ & $7.1^{b}$ \\
\hline $\mathrm{Mr}$ & $3.6^{b}$ & $3.1^{a}$ & $4.0^{c}$ & $3.0^{a, b}$ & $4.0^{\mathrm{b}, \mathrm{c}}$ & $5.0^{b}$ & $6.0^{\mathrm{b}, \mathrm{c}}$ & $6.7^{\mathrm{b}, \mathrm{c}}$ & $7.3^{b}$ \\
\hline Ap & $4.0^{\mathrm{b}, \mathrm{c}}$ & $3.7^{\mathrm{a}, \mathrm{b}}$ & $4.5^{\mathrm{c}, \mathrm{d}}$ & $3.7^{b}$ & $5.3^{c, d}$ & $5.5^{\mathrm{b}, \mathrm{c}}$ & $6.8^{c}$ & $6.9^{\mathrm{b}, \mathrm{c}}$ & $7.5^{b}$ \\
\hline My & $4.5^{c}$ & $4.3^{b}$ & $5.0^{d}$ & $4.2^{b, c}$ & $6.0^{\mathrm{d}, \mathrm{e}}$ & $6.0^{c}$ & $7.0^{c, d}$ & $7.0^{\mathrm{b}, \mathrm{c}}$ & $8.0^{b}$ \\
\hline Je & $4.5^{c}$ & $4.8^{b}$ & $5.0^{d}$ & $4.7^{c}$ & $6.0^{\mathrm{d}, \mathrm{e}}$ & $6.0^{c}$ & $7.5^{c, d}$ & $7.0^{\mathrm{b}, \mathrm{c}}$ & $10.0^{c}$ \\
\hline 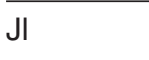 & $4.5^{c}$ & $5.4^{\mathrm{b}, \mathrm{c}}$ & $6.0^{\mathrm{d}, \mathrm{e}}$ & $5.3^{c, d}$ & $6.5^{\mathrm{e}}$ & $6.3^{c, d}$ & $7.5^{c, d}$ & $7.2^{b, c}$ & $10.5^{c}$ \\
\hline$\overline{\mathrm{Ag}}$ & $4.5^{c}$ & $6.0^{c}$ & $6.5^{\mathrm{e}}$ & $6.2^{d}$ & $6.6^{\mathrm{e}}$ & $6.5^{c, d}$ & $7.5^{c, d}$ & $7.2^{\mathrm{b}, \mathrm{c}}$ & $10.5^{c}$ \\
\hline Se & $4.6^{c}$ & $6.3^{c}$ & $7.0^{\mathrm{e}}$ & $6.3^{d}$ & $6.7^{\mathrm{e}}$ & $7.0^{d}$ & $7.8^{\mathrm{d}, \mathrm{e}}$ & $7.5^{\mathrm{c}, \mathrm{d}}$ & $11.0^{c}$ \\
\hline Oc & $4.6^{c}$ & $6.6^{c}$ & $7.2^{e}$ & $6.8^{\mathrm{d}, \mathrm{e}}$ & $7.0^{e, f}$ & $7.5^{\mathrm{d}, \mathrm{e}}$ & $8.7^{d}$ & $8.0^{c, d}$ & $11.4^{c, d}$ \\
\hline No & $5.0^{c}$ & $7.0^{c, d}$ & $7.5^{e, f}$ & $6.8^{\mathrm{d}, \mathrm{e}}$ & $7.4^{f}$ & $7.9^{\mathrm{d}, \mathrm{e}}$ & $10.3^{e}$ & $9.1^{\mathrm{d}, \mathrm{e}}$ & $12.8^{d}$ \\
\hline $\mathrm{De}$ & $5.0^{c}$ & $7.6^{d}$ & $7.9^{f}$ & $7.0^{\mathrm{e}}$ & $7.9^{f}$ & $8.8^{e}$ & $12.9^{f}$ & $10.3^{e}$ & $14.7^{\mathrm{e}}$ \\
\hline
\end{tabular}

† Standard deviations were routinely less than $5 \%$ of the means

${ }^{\ddagger}$ Means within a column followed by the same letter are not significantly different $(\mathrm{p} \leq 0.05)$ by the Duncan's Multiple Range Test

${ }^{1}$ EVOO from the present harvest season stored in deposits ${ }^{2}$ Bottled EVOO from the present harvest season ${ }^{3}$ Remaining EVOO from the previous harvest season stored in inert mill and bottled simultaneously with seasonal EVOO

Tasioula-Margari (2002) in that bottled EVOO reached $\mathrm{PV}$ values higher than $20 \mathrm{mEq} . \mathrm{O}_{2} / \mathrm{kg}$ oil for a storage period of eight months.

With respect to the $\mathrm{K}_{270}$ index, a marker of the stability of EVOO against peroxidation, it was always under the limits established by EEC Regulations. The evolution of this index for all EVOO varieties is shown in Table 4. Just as the above mentioned indexes, it significantly increased throughout the storage period $(p<0.05)$ Gutiérrez and Fernández (2002) reported that $\mathrm{K}_{270}$ was usually the first EVOO quality index to exceed the legal limit during storage. Nevertheless, in this work this situation has not been reproduced.

Chlorophylls and carotenoids are responsible for the color of EVOO, although this is not a parameter required by EEC Regulations to evaluate EVOO quality. Carotenoids are pigments that provide an intense color to foods (red, orange and yellow). The levels of carotenoids in the studied EVOOs (Table 5 ) decreased slightly in all storage conditions, in a similar trend for all EVOO varieties.

Chlorophylls have been described to act as prooxidants under light storage and as free radical quenching in the dark (Tsimidou et al., 2005). It can be observed (Table 6 ) that chlorophylls remained constant amounts in the dark glass bottles, while in transparent glass bottles, they diminished significantly with respect to the other storage conditions avoiding direct exposure to light $(p<0.05)$.

Few changes were observed in the FA composition throughout the storage period. (Table 7) The main FA of EVOO -OA-, slightly increased with time in all the EVOO varieties, especially in Picual EVOO stored in deposits, which reached a final percentage of total saponifiable oil above $80 \%$ (Table 7 ). These results agree with the study performed by Okogeri et al. (2002) and Morelló et al. (2004) who confirmed the increase of OA during storage as a result of the degradation of polyunsaturated acids, LA and -linolenic acid (ALA, 18:3n-3). Nevertheless in a study from Méndez and Falqué (2007), a reduction of $O A$ throughout the storage period is observed. In this study, a minor decrease in LA and ALA percentages was observed thoroughly the studied period (data not shown), which might explained the increase in OA percentage previously mentioned. This decrease was significant in the Picual variety $(p<0.05)$, in which the loss in LA reached $27 \%$, while for ALA an $11 \%$ was seen. Finally, PA decreases significantly throughout the storage period in Picual EVOO stored in deposits 
Table 4

$\mathrm{K}_{270}$ index evolution in three EVOO varieties stored under different variables for a 12 month period

\begin{tabular}{|c|c|c|c|c|c|c|c|c|c|}
\hline \multirow{3}{*}{ Months } & \multicolumn{9}{|c|}{ Olive oil varieties $^{t, \neq}$} \\
\hline & \multicolumn{5}{|c|}{ Picual } & \multicolumn{2}{|c|}{ Hojiblanca } & \multicolumn{2}{|c|}{ Arbequina } \\
\hline & ${ }^{1}$ Mill & ${ }^{2}$ Dark bot. & $\begin{array}{c}{ }^{2} \text { Transparent } \\
\text { bot. }\end{array}$ & $\begin{array}{c}{ }^{3} \text { Inert. dark } \\
\text { bot. }\end{array}$ & $\begin{array}{c}{ }^{3} \text { Inert. } \\
\text { transparent } \\
\text { bot. }\end{array}$ & ${ }^{2}$ Dark bot. & $\begin{array}{c}{ }^{2} \text { Transparent } \\
\text { bot. }\end{array}$ & ${ }^{2}$ Dark bot. & $\begin{array}{c}{ }^{2} \text { Transparent } \\
\text { bot. }\end{array}$ \\
\hline $\mathrm{Ja}$ & $0.06^{a}$ & $0.06^{a}$ & $0.06^{a}$ & $0.08^{a}$ & $0.08^{a}$ & $0.05^{a}$ & $0.05^{a}$ & $0.08^{a}$ & $0.08^{a}$ \\
\hline $\mathrm{Fe}$ & $0.06^{a}$ & $0.06^{a}$ & $0.06^{a}$ & $0.08^{a}$ & $0.08^{a}$ & $0.06^{a}$ & $0.09^{b}$ & $0.07^{a}$ & $0.08^{a}$ \\
\hline $\mathrm{Mr}$ & $0.09^{a, b}$ & $0.10^{b}$ & $0.09^{a, b}$ & $0.10^{a, b}$ & $0.10^{a, b}$ & $0.10^{b}$ & $0.11^{b, c}$ & $0.09^{a, b}$ & $0.11^{a, b}$ \\
\hline Ap & $0.12^{b}$ & $0.12^{\mathrm{b}, \mathrm{c}}$ & $0.12^{\mathrm{b}, \mathrm{c}}$ & $0.11^{\mathrm{a}, \mathrm{b}}$ & $0.12^{b, c}$ & $0.11^{b}$ & $0.11^{\mathrm{b}, \mathrm{c}}$ & $0.12^{\mathrm{b}, \mathrm{c}}$ & $0.12^{\mathrm{b}, \mathrm{c}}$ \\
\hline My & $0.12^{b}$ & $0.13^{b, c}$ & $0.13^{\mathrm{b}, \mathrm{c}}$ & $0.12^{b, c}$ & $0.12^{\mathrm{b}, \mathrm{c}}$ & $0.12^{\mathrm{b}, \mathrm{c}}$ & $0.12^{b, c}$ & $0.13^{\mathrm{b}, \mathrm{c}}$ & $0.13^{b, c}$ \\
\hline Je & $0.12^{b}$ & $0.12^{b, c}$ & $0.13^{b, c}$ & $0.12^{b, c}$ & $0.14^{b, c, d}$ & $0.12^{b, c}$ & $0.14^{c, d}$ & $0.13^{b, c}$ & $0.14^{\mathrm{b}, \mathrm{c}}$ \\
\hline 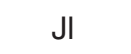 & $0.12^{b}$ & $0.12^{b, c}$ & $0.13^{b, c}$ & $0.12^{b, c}$ & $0.14^{b, c, d}$ & $0.12^{b, c}$ & $0.14^{c, d}$ & $0.13^{b, c}$ & $0.13^{b, c}$ \\
\hline $\mathrm{Ag}$ & $0.12^{b}$ & $0.12^{b, c}$ & $0.15^{\mathrm{c}, \mathrm{d}}$ & $0.13^{b, c}$ & $0.16^{\mathrm{c}, \mathrm{d}, \mathrm{e}}$ & $0.12^{b, c}$ & $0.15^{d}$ & $0.14^{c, d}$ & $0.14^{b, c}$ \\
\hline $\mathrm{Se}$ & $0.13^{b}$ & $0.14^{\mathrm{b}, \mathrm{c}}$ & $0.17^{c, d}$ & $0.13^{b, c}$ & $0.17^{\mathrm{d}, \mathrm{e}}$ & $0.13^{b, c}$ & $0.16^{d}$ & $0.15^{\mathrm{c}, \mathrm{d}}$ & $0.15^{c, d}$ \\
\hline Oc & $0.13^{b}$ & $0.14^{\mathrm{b}, \mathrm{c}}$ & $0.17^{c, d}$ & $0.13^{b, c}$ & $0.17^{\mathrm{d}, \mathrm{e}}$ & $0.13^{b, c}$ & $0.15^{d}$ & $0.14^{\mathrm{c}, \mathrm{d}}$ & $0.15^{\mathrm{c}, \mathrm{d}}$ \\
\hline No & $0.13^{b}$ & $0.14^{\mathrm{b}, \mathrm{c}}$ & $0.17^{\mathrm{c}, \mathrm{d}}$ & $0.14^{c}$ & $0.18^{e}$ & $0.13^{b, c}$ & $0.17^{d}$ & $0.15^{\mathrm{c}, \mathrm{d}}$ & $0.17^{\mathrm{d}, \mathrm{e}}$ \\
\hline $\mathrm{De}$ & $0.13^{b}$ & $0.15^{c}$ & $0.18^{d}$ & $0.15^{c}$ & $0.18^{e}$ & $0.14^{c}$ & $0.17^{d}$ & $0.16^{d}$ & $0.19^{e}$ \\
\hline
\end{tabular}

${ }^{\dagger}$ Standard deviations were routinely less than $5 \%$ of the means

${ }^{\ddagger}$ Means within a column followed by the same letter are not significantly different $(p \leq 0.05)$ by the Duncan's Multiple Range Test ${ }^{1}$ EVOO from the present harvest season stored in deposits ${ }^{2}$ Bottled EVOO from the present harvest season ${ }^{3}$ Remaining EVOO from the previous harvest season stored in inert mill and bottled simultaneously with seasonal EVOO

Table 5

Carotenoid value evolution in three EVOO varieties stored under different variables for a 12 month period

\begin{tabular}{|c|c|c|c|c|c|c|c|c|c|}
\hline \multirow{3}{*}{ Months } & \multicolumn{9}{|c|}{ Olive oil varieties ${ }^{t, \neq}$} \\
\hline & \multicolumn{5}{|c|}{ Picual } & \multicolumn{2}{|c|}{ Hojiblanca } & \multicolumn{2}{|c|}{ Arbequina } \\
\hline & ${ }^{1}$ Mill & ²Dark bot. & $\begin{array}{c}{ }^{2} \text { Transparent } \\
\text { bot. }\end{array}$ & $\begin{array}{l}{ }^{3} \text { Inert. dark } \\
\text { bot. }\end{array}$ & $\begin{array}{c}{ }^{3} \text { Inert. } \\
\text { transparent } \\
\text { bot. }\end{array}$ & ${ }^{2}$ Dark bot. & $\begin{array}{c}{ }^{2} \text { Transparent } \\
\text { bot. }\end{array}$ & ²Dark bot. & $\begin{array}{c}{ }^{2} \text { Transparent } \\
\text { bot. }\end{array}$ \\
\hline $\mathrm{Ja}$ & $6.7^{\mathrm{a}}$ & $6.7^{\mathrm{a}}$ & $6.7^{\mathrm{a}}$ & $10.7^{\mathrm{a}}$ & $10.7^{\mathrm{a}}$ & $6.5^{\mathrm{a}}$ & $6.5^{\mathrm{a}}$ & $5.3^{a}$ & $5.3^{a}$ \\
\hline $\mathrm{Fe}$ & $6.7^{\mathrm{a}}$ & $6.7^{\mathrm{a}}$ & $6.7^{\mathrm{a}}$ & $10.7^{a}$ & $10.7^{\mathrm{a}}$ & $6.6^{\mathrm{a}}$ & $6.6^{\mathrm{a}}$ & $5.1^{\mathrm{a}}$ & $5.0^{\mathrm{a}}$ \\
\hline $\mathrm{Mr}$ & $6.7^{\mathrm{a}}$ & $6.7^{\mathrm{a}}$ & $6.7^{\mathrm{a}}$ & $11.0^{\mathrm{a}}$ & $10.6^{a}$ & $6.7^{\mathrm{a}}$ & $6.2^{\mathrm{a}}$ & $4.9^{\mathrm{a}}$ & $4.8^{\mathrm{a}}$ \\
\hline$A p$ & $6.5^{\mathrm{a}}$ & $6.6^{a}$ & $6.2^{a}$ & $10.7^{a}$ & $10.5^{a}$ & $6.1^{a}$ & $6.2^{a}$ & $4.9^{a}$ & $4.9^{a}$ \\
\hline My & $6.3^{a}$ & $6.4^{\mathrm{a}}$ & $6.2^{\mathrm{a}}$ & $10.4^{a}$ & $10.4^{a}$ & $6.0^{\mathrm{a}}$ & $6.2^{\mathrm{a}}$ & $4.9^{a}$ & $4.7^{\mathrm{a}}$ \\
\hline Je & $5.9^{a}$ & $6.0^{a, b}$ & $5.6^{a, b}$ & $10.7^{a}$ & $10.5^{a}$ & $6.0^{a}$ & $5.9^{a}$ & $4.5^{a}$ & $4.2^{a}$ \\
\hline 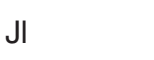 & $5.9^{a}$ & $5.6^{\mathrm{a}, \mathrm{b}}$ & $5.6^{a, b}$ & $10.5^{a}$ & $10.5^{\mathrm{a}}$ & $6.0^{\mathrm{a}}$ & $6.0^{\mathrm{a}}$ & $4.5^{\mathrm{a}}$ & $4.2^{\mathrm{a}}$ \\
\hline $\mathrm{Ag}$ & $5.9^{a}$ & $5.7^{\mathrm{a}, \mathrm{b}}$ & $5.7^{\mathrm{a}, \mathrm{b}}$ & $9.9^{a}$ & $9.9^{a}$ & $5.9^{a}$ & $6.0^{\mathrm{a}}$ & $4.5^{\mathrm{a}}$ & $4.3^{\mathrm{a}}$ \\
\hline $\mathrm{Se}$ & $6.0^{\mathrm{a}}$ & $5.2^{b}$ & $5.3^{b}$ & $9.8^{a}$ & $9.8^{a}$ & $5.8^{a}$ & $5.9^{a}$ & $4.5^{a}$ & $4.5^{\mathrm{a}}$ \\
\hline Oc & $6.1^{\mathrm{a}}$ & $5.3^{b}$ & $5.3^{b}$ & $9.8^{a}$ & $9.8^{a}$ & $5.5^{\mathrm{a}}$ & $5.7^{a}$ & $4.5^{\mathrm{a}}$ & $4.2^{\mathrm{a}}$ \\
\hline No & $6.0^{a}$ & $5.4^{b}$ & $5.4^{b}$ & $9.8^{a}$ & $9.8^{a}$ & $5.6^{a}$ & $5.5^{\mathrm{a}}$ & $4.5^{\mathrm{a}}$ & $4.3^{a}$ \\
\hline $\mathrm{De}$ & $6.0^{\mathrm{a}}$ & $5.4^{\mathrm{b}}$ & $5.4^{\mathrm{b}}$ & $9.7^{\mathrm{a}}$ & $9.7^{\mathrm{a}}$ & $5.6^{\mathrm{a}}$ & $5.4^{\mathrm{a}}$ & $4.5^{\mathrm{a}}$ & $4.3^{a}$ \\
\hline
\end{tabular}

+ Standard deviations were routinely less than $5 \%$ of the means

${ }^{\ddagger}$ Means within a column followed by the same letter are not significantly different $(p \leq 0.05)$ by the Duncan's Multiple Range Test

${ }^{1}$ EVOO from the present harvest season stored in deposits ${ }^{2}$ Bottled EVOO from the present harvest season ${ }^{3}$ Remaining EVOO from the previous harvest season stored in inert mill and bottled simultaneously with seasonal EVOO 
Table 6

Chlorophyll value evolution in three EVOO varieties stored under different variables for a 12 month period

\begin{tabular}{|c|c|c|c|c|c|c|c|c|c|}
\hline \multirow{3}{*}{ Months } & \multicolumn{9}{|c|}{ Olive oil varieties $^{\dagger, \neq}$} \\
\hline & \multicolumn{5}{|c|}{ Picual } & \multicolumn{2}{|c|}{ Hojiblanca } & \multicolumn{2}{|c|}{ Arbequina } \\
\hline & ${ }^{1}$ Mill & ${ }^{2}$ Dark bot. & $\begin{array}{c}{ }^{2} \text { Transparent } \\
\text { bot. }\end{array}$ & $\begin{array}{c}{ }^{3} \text { Inert. dark } \\
\text { bot. }\end{array}$ & $\begin{array}{c}{ }^{3} \text { Inert. } \\
\text { transparent } \\
\text { bot. }\end{array}$ & ${ }^{2}$ Dark bot. & $\begin{array}{c}{ }^{2} \text { Transparent } \\
\text { bot. }\end{array}$ & ²Dark bot. & $\begin{array}{c}{ }^{2} \text { Transparent } \\
\text { bot. }\end{array}$ \\
\hline $\mathrm{Ja}$ & $8.0^{a}$ & $8.0^{a}$ & $8.0^{a}$ & $15.8^{\mathrm{a}}$ & $15.8^{a}$ & $4.7^{\mathrm{a}}$ & $4.7^{\mathrm{a}, \mathrm{b}}$ & $7.2^{\mathrm{a}}$ & $7.2^{a}$ \\
\hline $\mathrm{Fe}$ & $7.9^{a}$ & $8.0^{\mathrm{a}}$ & $7.7^{\mathrm{a}, \mathrm{b}}$ & $15.8^{a}$ & $15.1^{\mathrm{a}}$ & $4.5^{\mathrm{a}}$ & $4.2^{\mathrm{a}, \mathrm{b}}$ & $7.1^{\mathrm{a}}$ & $7.2^{\mathrm{a}}$ \\
\hline $\mathrm{Mr}$ & $7.9^{a}$ & $7.8^{\mathrm{a}}$ & $7.6^{\mathrm{a}, \mathrm{b}}$ & $15.5^{a}$ & $15.5^{\mathrm{a}}$ & $4.3^{a}$ & $4.0^{\mathrm{a}, \mathrm{b}}$ & $7.0^{\mathrm{a}}$ & $7.0^{\mathrm{a}}$ \\
\hline Ap & $7.1^{\mathrm{a}}$ & $7.8^{\mathrm{a}}$ & $7.6^{\mathrm{a}, \mathrm{b}}$ & $15.6^{a}$ & $15.8^{a}$ & $4.3^{\mathrm{a}}$ & $4.9^{\mathrm{a}, \mathrm{b}}$ & $6.9^{\mathrm{a}}$ & $6.9^{a}$ \\
\hline My & $7.1^{\mathrm{a}}$ & $7.7^{\mathrm{a}}$ & $7.5^{\mathrm{a}, \mathrm{b}}$ & $15.3^{a}$ & $15.3^{a}$ & $4.2^{\mathrm{a}}$ & $5.6^{\mathrm{a}}$ & $6.8^{\mathrm{a}}$ & $6.5^{\mathrm{a}}$ \\
\hline Je & $7.0^{\mathrm{a}}$ & $7.6^{a, b}$ & $6.6^{\mathrm{b}}$ & $15.6^{a}$ & $15.9^{a}$ & $4.1^{\mathrm{a}}$ & $4.7^{\mathrm{a}, \mathrm{b}}$ & $6.7^{\mathrm{a}}$ & $4.0^{b}$ \\
\hline 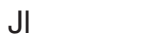 & $7.0^{\mathrm{a}}$ & $6.5^{\mathrm{b}, \mathrm{c}}$ & $4.5^{c}$ & $15.9^{a}$ & $15.9^{a}$ & $4.0^{\mathrm{a}}$ & $3.6^{b}$ & $6.3^{a, b}$ & $1.5^{\mathrm{c}}$ \\
\hline $\mathrm{Ag}$ & $7.2^{\mathrm{a}}$ & $6.4^{b, c}$ & $1.5^{\mathrm{d}}$ & $14.6^{a, b}$ & $11.1^{b}$ & $4.2^{\mathrm{a}}$ & $2.2^{c}$ & $5.9^{a, b}$ & $0.9^{d}$ \\
\hline $\mathrm{Se}$ & $7.0^{\mathrm{a}}$ & $5.8^{c}$ & $1.4^{\mathrm{d}}$ & $13.9^{a, b}$ & $10.7^{b}$ & $4.1^{\mathrm{a}}$ & $2.2^{c}$ & $5.5^{\mathrm{b}}$ & $0.8^{d}$ \\
\hline Oc & $6.9^{a}$ & $5.7^{c}$ & $1.4^{d}$ & $13.7^{b}$ & $10.0^{b}$ & $4.1^{\mathrm{a}}$ & $1.4^{\mathrm{d}}$ & $5.4^{b}$ & $0.7^{d}$ \\
\hline No & $6.7^{\mathrm{a}}$ & $4.9^{c}$ & $1.0^{\mathrm{e}}$ & $13.5^{b}$ & $10.1^{b}$ & $4.0^{\mathrm{a}}$ & $1.3^{d}$ & $4.7^{b}$ & $0.6^{d}$ \\
\hline $\mathrm{De}$ & $6.7^{\mathrm{a}}$ & $4.7^{c}$ & $0.8^{e}$ & $13.2^{b}$ & $9.9^{b}$ & $4.0^{\mathrm{a}}$ & $1.2^{d}$ & $4.6^{b}$ & $0.6^{d}$ \\
\hline
\end{tabular}

${ }^{\dagger}$ Standard deviations were routinely less than $5 \%$ of the means

${ }^{\ddagger}$ Means within a column followed by the same letter are not significantly different $(p \leq 0.05)$ by the Duncan's Multiple Range Test

${ }^{1}$ EVOO from the present harvest season stored in deposits ${ }^{2}$ Bottled EVOO from the present harvest season ${ }^{3}$ Remaining EVOO from the previous harvest season stored in inert mill and bottled simultaneously with seasonal EVOO

Table 7

Oleic acid evolution in three EVOO varieties stored under different variables for a 12 month period

\begin{tabular}{|c|c|c|c|c|c|c|c|c|c|}
\hline \multirow{3}{*}{ Months } & \multicolumn{9}{|c|}{ Olive oil varieties $^{\dagger, \ddagger}$} \\
\hline & \multicolumn{5}{|c|}{ Picual } & \multicolumn{2}{|c|}{ Hojiblanca } & \multicolumn{2}{|c|}{ Arbequina } \\
\hline & ${ }^{1}$ Mill & ${ }^{2}$ Dark bot. & $\begin{array}{c}{ }^{2} \text { Transparent } \\
\text { bot. }\end{array}$ & $\begin{array}{l}{ }^{3} \text { Inert. dark } \\
\text { bot. }\end{array}$ & $\begin{array}{l}{ }^{3} \text { Inert. } \\
\text { transparent } \\
\text { bot. }\end{array}$ & ${ }^{2}$ Dark bot. & $\begin{array}{c}{ }^{2} \text { Transparent } \\
\text { bot. }\end{array}$ & ²Dark bot. & $\begin{array}{c}{ }^{2} \text { Transparent } \\
\text { bot. }\end{array}$ \\
\hline $\mathrm{Ja}$ & $77.4^{a}$ & $77.5^{a}$ & $77.5^{a}$ & $79.9^{a}$ & $79.8^{a}$ & $74.5^{\mathrm{a}}$ & $74.5^{a}$ & $64.5^{a}$ & $63.9^{a}$ \\
\hline $\mathrm{Fe}$ & $77.3^{a}$ & $77.8^{a}$ & $77.9^{a}$ & $80.1^{a}$ & $80.0^{a}$ & $74.1^{\mathrm{a}}$ & $74.3^{a}$ & $63.4^{\mathrm{a}}$ & $64.8^{a}$ \\
\hline $\mathrm{Mr}$ & $76.8^{a}$ & $78.5^{a}$ & $78.5^{\mathrm{a}}$ & $80.5^{a}$ & $80.1^{a}$ & $74.1^{\mathrm{a}}$ & $74.1^{\mathrm{a}}$ & $64.6^{a}$ & $64.5^{\mathrm{a}}$ \\
\hline Ap & $77.5^{a}$ & $78.7^{\mathrm{a}}$ & $78.5^{a}$ & $80.4^{a}$ & $80.1^{a}$ & $74.2^{\mathrm{a}}$ & $74.5^{\mathrm{a}}$ & $64.1^{\mathrm{a}}$ & $64.0^{\mathrm{a}}$ \\
\hline My & $77.7^{\mathrm{a}}$ & $78.8^{a}$ & $78.7^{\mathrm{a}}$ & $80.3^{a}$ & $80.2^{a}$ & $74.0^{a}$ & $74.5^{\mathrm{a}}$ & $64.8^{a}$ & $64.2^{\mathrm{a}}$ \\
\hline Je & $77.5^{\mathrm{a}}$ & $78.7^{\mathrm{a}}$ & $78.9^{a}$ & $79.8^{a}$ & $79.9^{a}$ & $74.5^{a}$ & $75.2^{a}$ & $64.3^{a}$ & $64.5^{\mathrm{a}}$ \\
\hline J & $77.8^{a}$ & $78.2^{a}$ & $78.1^{\mathrm{a}}$ & $80.0^{a}$ & $80.1^{a}$ & $74.1^{\mathrm{a}}$ & $75.3^{a}$ & $64.1^{\mathrm{a}}$ & $64.3^{a}$ \\
\hline $\mathrm{Ag}$ & $79.8^{a, b}$ & $78.3^{a}$ & $78.4^{\mathrm{a}}$ & $79.3^{a}$ & $79.3^{a}$ & $75.0^{a}$ & $75.3^{a}$ & $64.1^{a}$ & $65.1^{a}$ \\
\hline $\mathrm{Se}$ & $80.8^{a, b}$ & $79.2^{a}$ & $78.3^{a}$ & $80.2^{a}$ & $79.3^{a}$ & $75.1^{a}$ & $75.2^{a}$ & $64.2^{a}$ & $65.1^{a}$ \\
\hline Oc & $80.0^{a, b}$ & $78.5^{a}$ & $77.9^{a}$ & $81.3^{a}$ & $81.0^{a}$ & $74.7^{a}$ & $74.7^{a}$ & $64.5^{a}$ & $64.9^{a}$ \\
\hline No & $81.2^{b}$ & $78.7^{a}$ & $78.8^{a}$ & $81.0^{a}$ & $80.1^{a}$ & $75.1^{a}$ & $75.1^{\mathrm{a}}$ & $64.9^{a}$ & $65.8^{a}$ \\
\hline $\mathrm{De}$ & $81.9^{b}$ & $79.4^{a}$ & $79.1^{\mathrm{a}}$ & $81.1^{a}$ & $80.8^{a}$ & $75.2^{a}$ & $75.2^{a}$ & $65.0^{\mathrm{a}}$ & $66.7^{\mathrm{a}}$ \\
\hline
\end{tabular}

${ }^{\dagger}$ Standard deviations were routinely less than $5 \%$ of the means

${ }^{\ddagger}$ Means within a column followed by the same letter are not significantly different $(p \leq 0.05)$ by the Duncan's Multiple Range Test

${ }^{1}$ EVOO from the present harvest season stored in deposits ${ }^{2}$ Bottled EVOO from the present harvest season ${ }^{3}$ Remaining EVOO from the previous harvest season stored in inert mill and bottled simultaneously with seasonal EVOO 
$(p<0.05)$ (data not shown). This fact could be attributed to a lower melting point of the PA-enriched triglycerides than others in which OA and PUFA predominate. In this sense, Picual EVOO has been reported to contain up to $0.5 \%$ of tripalmitin and $3.43 \%$ of other structured tryglicerides PA-PA-OA (Osorio et al. 2003). These higher-melting point triglycerides led to the formation of granular crystals below $20^{\circ} \mathrm{C}$ (Tanakal et al. 2007), the temperature at which Picual EVOO was stored. Thus, a minor winterization process could be achieved, in which PA-triglycerides slowly settle down during the storage period. This way, this process also contributes to the previous OA upgrading noted in EVOO during storage. At the same time, the higher percentage of OA noted in Picual EVOO from the previous crop season and stored in an inert mill (Table 1) is consistent with these statements.

\section{Multifactor ANOVA Test}

A multifactor analysis of the variance (ANOVA) was accomplished by computing all the data obtained here. The variables significantly affecting results were storage type (F-Ratio $3.41 ; p<0.05$ ) and EVOO variety (F-Ratio 60.8; $p<0.05$ ). In reference to EVOO storage, statistically significant differences were found among glass bottles types, but not between mill and bottles $(p<0.05)$. On the other hand, the three EVOO varieties here considered changed during storage with a different statistical pattern $(\mathrm{p}<0.05)$. In addition, the analyzed parameters having a statistically similar trend were acidity- $\mathrm{K}_{270}$ index, IP-chlorophylls, and carotenoidschlorophylls $(p<0.05)$.

\section{CONCLUSIONS}

This study shows that several varieties of EVOO stored for twelve months in different packaging conditions still had the quality attributes of EVOO. Arbequina EVOO showed major changes throughout the storage period, while Picual EVOO was the most stable. The better results for the evolution of quality parameters in all EVOO varieties were observed in oils packaged in deposits or in dark glass bottles. In addition, a significant increase in OA was observed during the storage period in EVOO stored in mills. In addition, this study demonstrated that EVOO collected from the previous harvesting season and stored under nitrogen atmosphere could be packaged in glass bottles without appreciable quality changes, as compared with seasonal EVOO packaged in similar bottles.

\section{ACKNOWLEDGMENTS}

The authors thank the Spanish Ministry of Science and Technology (project AGL200762838/ALI), and the Ministry of Innovation, Science and Enterprise of the Andalusian Government
(Spain) (project AGR1571), for their financial support. The company "Olivar del Desierto, S.L.", is also acknowledged for the supply of their oil, that make possible the accomplishment of this work.

\section{REFERENCES}

Caponio F, Bilancia MT, Pasqualone A, Sikorska E, Gomes T. 2005. Influence of the exposure to light on extra virgin olive oil quality during storage. Europ. Food Res. and Tech. 221, 92-98.

Coutelieris FA, Kanavouras A. 2006. Experimental and theoretical investigation of packaged olive oil: Development of a quality indicator based on mathematical predictions. J. Food Eng. 73, 85-92.

European Union Commission. 1991. Regulation EEC/2568/91 on the Characteristics of Olive and Olive Pomance Oils and their Analytical Methods. Annexes II, III, IX and XII. Offic. J. Europ. Comm. 248, 6-36.

Gallardo-Guerrero L, Gandul-Rojas B, Roca M, MínguezMosquera M. 2005. Effect of storage on the original pigment profile of Spanish virgin olive oil. J. Am. Oil Chem. Soc. 82, 33-39

Giovacchino DIL, Mucciarella N, Constantini N, Ferrante ML, Surricchio G. 2002. Use of nitrogen to improve stability of virgin olive oil during storage. J. Amer. Oil Chem. Soc. 79, 339-344.

Gómez-Alonso S, Mancebo-Campos V, Salvador MD, Fregapane G. 2007. Evolution of major and minor components and oxidation indexes of virgin olive oil during 21 months storage at room temperature. Food Chem. 100, 36-42.

Gutiérrez F, Fernández JL. 2002. Determinant parameters and components in the storage of virgin olive oil. Prediction of storage time beyond which the oil is no longer of extra quality. J. Agric. Food Chem. 50, 571-577.

Hrncirik K, Fritsche S. 2005. Relation between the Endogenous Antioxidant System and the quality of Extra Virgin Olive Oil under accelerated storage conditions. J. Agric. Food Chem. 53, 2103-2110.

Kanavouras A, Coutelieris FA. 2006. Shelf-life predictions for packaged olive oil based on simulations. Food Chem. 96, 48-55.

Kiritsakis AK. 1992. El aceite de oliva. AMV, Madrid, Spain.

Lepage G, Roy C. 1984. Improved recovery of fatty acid through direct transesterification without prior extraction or purification J. Lipid Res. 25, 1391-1396.

Méndez A, Falqué E. 2007. Effect of storage time and container type on the quality of extra-virgin olive oil. Food Control 18, 521 - 529.

Mínguez-Mosquera MI, Gandul-Rojas B, GarridoFernández J, Gallardo-Guerrero L. 1990. Pigments present in virgin olive oil. J. Amer. Oil Chem. Soc. 67, 192-196.

Morelló J, Motilva MJ, Tovar MJ, Romero M.P. 2004. Changes in commercial virgin olive oil (cv Arbequina) during storage, with special emphasis on the phenolic fraction. Food Chem. 85, 357-364

Okogeri O, Tasioula-Margari M. 2002. Changes occurring in phenolic compounds and --tocopherol of virgin olive oil during storage. J. Agric. Food Chem. 50, 1077-1080.

Osorio Bueno E, Sánchez Casas JJ, Martínez Cano M, Montaño García AM. 2003. Estudio del contenido en triglicéridos de aceites monovarietales elaborados a 
partir de aceitunas producidas en la región extremeña. Grasas y Aceites 54, 1-6.

Pagliarini E, Zanoni B, Giovanelli G. 2000. Predictive study on Tuscan extra virgin olive oil stability under several commercial conditions. J. Agric. Food Chem. 48, 1345-1351.

Perona J, Arcemis C, Ruiz-Gutiérrez V, Catalá A. 2005. Effect of Dietary High-Oleic-Acid Oils that are Rich in Antioxidants on Microsomal Lipid Peroxidation in Rats J. Agric. Food Chem. 53, 730-735.

Perona JS, Ruiz-Gutiérrez V. 2000. Effect of two high-oleic oils on the liver lipid composition of spontaneously hypertensive rats. Life Sci. 66, 521-531.

Psomiadou E, Tsimidou M. 2002. Stability of virgin olive oil. II. Photo-oxidation studies. J. Agric. Food Chem. 50, 7 22-727.

Ramírez-Tortosa MC, Urbano G, López-Jurado $M$, Nestares T, Gómez MC, Mir A, Ros E, Mataix J, Gil A. 1999. Extra-Virgin Olive Oil Increases the Resistance of LDL to Oxidation More than Refined Olive Oil in Free-Living Men with Peripheral Vascular Disease. J. Nutr. 129, 2177-2183.

Serra-Majem LI, Ngo de la Cruz J, Ribas L, Tur JA. 2003. Olive oil and the Mediterranean diet: beyond the rhetoric. Europ. J. Clin. Nutr. 57, S2-S7.
Tanaka L, Miura S, Yoshioka T. 2007. Formation of granular crystals in margarine with excess amount of palm oil. J. Amer. Oil Chem. Soc. 84, 421-426.

Tawfikk MS, Huyghebaert A. 1997. Interaction of packaging materials and vegetable oils: Stability. Food Chem. 64, 451-459.

Tsimidou MZ, Georgiou A, Koidis A, Boskou D. 2005. Loss of stability of "veiled" (cloudy) virgin olive oils in storage. Food Chem. 93, 377-383.

Uceda M, Hermoso M. 1998. La calidad del aceite de oliva, in Barranco D, Fernández-Escobar R, Rallo L (Eds.) El cultivo del olivo, Coedición Junta de Andalucía- Mundi Prensa, Madrid, pps. 589-614.

Vekiari S.A., Papadopouloua P., Koutsaftakisb A. 2002. Comparison of different olive oil extraction systems and the effect of storage conditions on the quality of the virgin olive oil. Grasas y Aceites 53, 324-329

Vekiari SA, Papadopoulou P, Kiritsakis A. 2007. Effects of processing methods and commercial storage conditions on the extra virgin olive oil quality indexes. Grasas y Aceites 58, 237-242. 